\title{
A Comparison between Biocompatibilities of Nanocomposites of Silica Doped in HA/collagen and those Doped in HA/gelatin
}

\section{FARIBA NAJAFIZADEH ${ }^{1}$, MIR ABDULLAH SEYED SADJADI ${ }^{1 *}$, SEYED JEMILADINE FATEMI $^{2}$, MAHMOOD KARIMI MOBARAKEH ${ }^{3}$ and REZA MALEKPOUR AFSHAR ${ }^{4}$}

\author{
${ }^{1}$ Department of Inorganic Chemistry, Science and Research Branch, \\ Islamic Azad University, Tehran, Iran. \\ 2Department of Chemistry, Basic Sciences Faculty, \\ Islamic Azad and Shahid Bahonar University, Kerman, Iran. \\ ${ }^{3}$ Department of Trauma and Orthopedic Surgery, \\ Kerman University of Medical Sciences, Kerman, Iran. \\ ${ }^{4}$ Department of pathology, Medical school, P.O Box 444, \\ Kerman University of Medical Sciences, Kerman, Iran. \\ ${ }^{\star}$ Corresponding author E-mail: m.s.sadjad@gmail.com
}

http://dx.doi.org/10.13005/ojc/320331

(Received: March 22, 2016; Accepted: April 30, 2016)

\begin{abstract}
In this study, biocompatibility of nano composites of silica doped in HA/collagen was compared against those doped in $\mathrm{HA} /$ gelatin. For this purpose, hydrothermal samples were synthesized before being investigated by X-ray diffraction (XRD) and Fourier transform infrared spectroscopy (FT-IR). Size and morphology of the samples were further characterized by scanning and transmission electron microscopy (SEM). Moreover, energy-dispersive X-ray spectroscopy (EDS) was used to undertake an elemental analysis on the prepared composites. FTIR spectras confirmed chemical structure of the nano composites and EDS patterns showed that, even though the nano composites of silica doped in $\mathrm{HA} /$ collagen had equivalent $\mathrm{Ca} / \mathrm{P}$ ratios to the theoretical value as repeated for $\mathrm{HA}$ chemical structure of $\mathrm{Ca}_{10}\left(\mathrm{PO}_{4}\right)_{6}(\mathrm{OH})_{2}$, corresponding $\mathrm{Ca} / \mathrm{P}$ ratios to the nano composites of silica doped in $\mathrm{HA} /$ gelatin were just close to the theoretical value. A comparison on the obtained XRD patterns showed that, the nano composites of silica doped in $\mathrm{HA} /$ collagen had their crystallite size smaller than that of the nano composites of silica doped in HA/gelatin. FESEM images indicated smaller particle sizes for the nano composites of silica doped in $\mathrm{HA} /$ collagen, as compared to those doped in $\mathrm{HA} /$ gelatin. Reduced crystallite size and decreased particle size are known to be associated with larger contact surface in chemical reactions, leading to better pharmacological efficacy in terms of bone repair.
\end{abstract}

Keywords: hydroxyapatite, gelatin, collagen, silica, nanocomposite. 


\section{INTRODUCTION}

Improving biomaterials for enhanced osseointegration and tissue engineering (for bone remodeling) represents an international research target. Some of the most significant approaches to such a target have been reviewed in a special issue of Science ${ }^{1}$. During the last decade, a considerable deal of attention has been directed towards the use of bioactive materials, where bioactivity is defined as interfacial bonding of an implant or a bioactive scaffold to tissue by forming a biologically active hydroxyapatite $(\mathrm{HA})$ layer on the bioactive material surface ${ }^{2}$. Among all calcium phosphate bioceramics, $\mathrm{HA}$ (with the chemical formula of $\mathrm{Ca}_{10}(\mathrm{PO} 4)_{6}(\mathrm{OH})_{2}$ ) is the most extensively used, biocompatible ceramic material for bone tissue engineering, as it has its chemical composition well-similar to those of the bone mineral phase ${ }^{3}$. A recently established materials concept of biomimetic composites based on silica, collagen, and calcium phosphates was adapted for the preparation of porous scaffolds suitable for tissue engineering applications ${ }^{4-6}$. Synthetic biodegradable scaffolds are becoming highly promising materials for bone substitution and regeneration ${ }^{7}$. They can provide an adequate structural support and a 3-D system on which cells can grow and migrate while the tissue regenerates, acting as a temporary extracellular matrix inducing the natural process of tissue regeneration and development ${ }^{8}$. The use of bioactive HA coatings on metal implant surfaces have been reported to improve fixation in orthopedic implants, especially during early stages of healing ${ }^{9,10,11}$. The requirement for biomaterials to assist in many medical applications replacing original musculoskeletal tissues and improve quality of life is rapidly increasing. HA has been widely used, as a bone graft material, in a range of medical and dental applications. However, pure HA suffers from low reactivity with existing bone ${ }^{12,13}$. HA and calciumdeficient $\mathrm{HA}$ in nano-particulate form are beginning to play significant roles in bone-related therapies owing to their unique functional properties including high surface area-to-volume ratio and ultrafine structure, which are similar to those of biological apatite. This similarity is of importance in cell-biomaterial interactions ${ }^{14-19}$.

\section{EXPERIMENTAL}

\section{Synthesis of nanocomposites of silica doped in HA/collagen}

In situ synthesis of HA rods was carried out in a collagen matrix. In order to prepare modified HA, $2.8 \mathrm{~g}$ of collagen was mixed with $70 \mathrm{ml}$ of distilled water while continuously applying a magnetic stirrer at its maximum speed at around $70^{\circ} \mathrm{C}$. After stirring for $2 \mathrm{~h}, 80 \mathrm{ml}$ of $0.1 \mathrm{M}$ calcium chloride solution was gradually added to the prepared biopolymer solution. The solution was subsequently stirred for $1 \mathrm{~h}$ before introducing $48 \mathrm{ml}$ of $0.1 \mathrm{M}$ sodium phosphate in a drop wise fashion while stirred at a $\mathrm{pH}$ value of 10 . The solution was placed in an oven at $100^{\circ} \mathrm{C}$ and kept for half an hour before filtering the formed precipitate. Once finished with preparing collagenbased HA nanocomposite, $30 \mathrm{cc}$ of double-distilled water along with $7.0 \mathrm{~g}$ of $\mathrm{Na}_{2} \mathrm{SiO}_{3}$ were mixed in a beaker and then introduced into the solution while stirred for half an hour at $36.5^{\circ} \mathrm{C}$. The samples were incubated at $36.5^{\circ} \mathrm{C}$ for $72 \mathrm{~h}$ after which time they were filtered and washed with double-distilled water, and then were dried at room temperature.
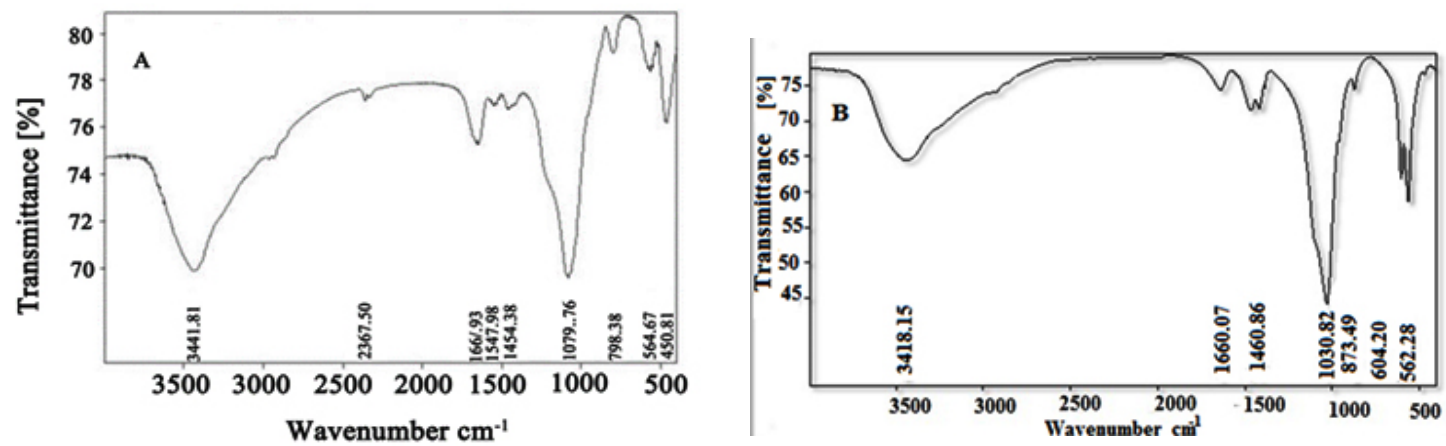

Fig. 1: FT-IR spectra for nanocomposites of silica doped in: A) HA/collagen, and B) HA/gelatin 
Synthesis of nanocomposites of silica doped in HA/gelatin

All synthesis steps explained in Section 2.1 were repeated with gelatin instead of collagen.

Table 1: Important Infrared Peaks Assigned To The Synthesized Nanocomposites

\begin{tabular}{lc}
\hline Nanocomposites & The wavelength $\mathbf{~ c m}^{-1}$ \\
\hline Crystal structure of HA & $464,605,566$ \\
P-O Stretching & 1036 \\
O-H Stretching & 3851 \\
N-H stretching & 3443 \\
C=O vibration & 1651 \\
\hline
\end{tabular}

Table 2: A Comparison Between Particle Sizes of the two Nanocomposite Samples

\begin{tabular}{lc}
\hline Sample & Particle size \\
\hline $\mathrm{HA}+\mathrm{Si}+$ gelatin & $54.07 \mathrm{~nm}$ \\
$\mathrm{HA}+\mathrm{Si}+$ collagen & $46.85 \mathrm{~nm}$ \\
\hline
\end{tabular}

Table 4: EDS Quantitative Results For Silica Nanoparticles Doped In HA/Gelatin

\begin{tabular}{lcc}
\hline Elt & W\% & A\% \\
\hline $\mathrm{C}$ & 12.11 & 18.82 \\
$\mathrm{O}$ & 49.38 & 57.62 \\
$\mathrm{Na}$ & 7.69 & 6.69 \\
$\mathrm{Si}$ & 8.36 & 5.55 \\
$\mathrm{P}$ & 8.67 & 4.90 \\
$\mathrm{Ca}$ & 13.79 & 6.42 \\
& 100.0 & 100.0 \\
\hline
\end{tabular}

\section{RESULTS AND DISCUSSION}

Fourier transform infrared spectroscopy (FTIR)

Fig. 1 provides a comparison between FT-IR spectrum captured for synthesized nanocomposites of silica doped in $\mathrm{HA} /$ collagen (Fig. $1 \mathrm{~A}$ ) and that of HA/gelatin (Fig. 1 B).

The peaks at of $562 \mathrm{~cm}^{-1}$ at $603 \mathrm{~cm}^{-1}$ specify crystal structure of $\mathrm{HA}$, while the peak at $1617 \mathrm{~cm}^{-1}$ specifies $\mathrm{N}-\mathrm{H}, \mathrm{C}-\mathrm{H}$ stretching in collagen. The peak within $3200-3500 \mathrm{~cm}^{-1}$ attributes to the absorption of $\mathrm{H}_{2} \mathrm{O}$ on $\mathrm{HA}$, with the one at $1010 \mathrm{~cm}^{-1}$ representing $\mathrm{P}-\mathrm{O}$ stretching. The peak at $875 \mathrm{~cm}^{-1}$ specifies C-O stretching related to $\mathrm{CO}_{2}$ content of the air. The peak

Table 3: A Comparison Between Crystallite Sizes Of The Nanocomposite Samples

\begin{tabular}{lcc}
\hline Samples & $\begin{array}{c}\text { Crystallite } \\
\text { size }[\AA]\end{array}$ & $\begin{array}{c}\text { Crystallite } \\
\text { size }[\mathrm{nm}]\end{array}$ \\
\hline$(\mathrm{HA}+$ Gelatin $+\mathrm{Si})$ & 1073 & $10.73 \mathrm{~nm}$ \\
$(\mathrm{HA}+$ Collagen $+\mathrm{Si})$ & 419 & $4.19 \mathrm{~nm}$ \\
\hline
\end{tabular}

Table 5: EDS Quantitative Results For Silica Nanoparticles Doped In HA/Collagen

\begin{tabular}{lcc}
\hline Elt & W\% & A\% \\
\hline $\mathrm{C}$ & 10.36 & 16.68 \\
$\mathrm{O}$ & 48.24 & 58.27 \\
$\mathrm{Na}$ & 3.67 & 4.79 \\
$\mathrm{Si}$ & 8.70 & 5.99 \\
$\mathrm{P}$ & 10.85 & 5.54 \\
$\mathrm{Ca}$ & 18.13 & 8.74 \\
& 100.0 & 100.0 \\
\hline
\end{tabular}

Table 6: A Comparison Between Ca/P Ratios of The Two Nanocomposite Samples

\begin{tabular}{lcl}
\hline Samples & Ca/P ratio & Comments \\
\hline $\mathrm{HA}+\mathrm{Si}+$ gelatin & 1.59 & Close to the theoretical value \\
$\mathrm{HA}+\mathrm{Si}+$ collagen & 1.67 & Equivalent to the theoretical value \\
& & \\
\hline
\end{tabular}


at $1175 \mathrm{~cm}^{-1}(\mathrm{C}-\mathrm{H}, \mathrm{N}-\mathrm{H})$ refers to stretching amine (II), confirming the presence of HA/collagen. Nonpresence of peaks related to the vibration absorption of Si-H $\left(2100 \mathrm{~cm}^{-1}\right)$ and Si-O bonds $\left(1100 \mathrm{~cm}^{-1}\right)$ in the spectrums proves the silica sample to be doped.

Table 1 reports several important infrared peaks assigned to the synthesized nanocomposites, confirming the formation of both products.

Field emission scanning electron microscopy (FESEM)

Fig. 2 comes with FESEM spectra for the synthesized silica nanocomposites doped in $\mathrm{HA}$ / gelatin (A) and HA/collagen (B). Table 2 indicates particle sizes for synthesized silica nanoparticles doped in HA/gelatin (54.07 nm) and HA/collagen (46.85 $\mathrm{nm})$.

\section{X-ray diffraction (XRD)}

Fig. 3 shows XRD patterns for silica nanoparticles doped in $\mathrm{HA} /$ collagen $(\mathrm{A})$ and $\mathrm{HA}$ / gelatin (B). The XRD peaks confirm crystalline planes of HA crystal system ${ }^{20}$. On the other hand, the presence of silica dope in nanocomposites cannot change the HA crystal system.

Table 3 shows crystallite sizes of the synthesized silica nanoparticles doped in $\mathrm{HA} /$ gelatin (10.73 nm) and HA/collagen (4.19 nm).

\section{Energy-dispersive X-ray spectroscopy (EDS)}

Elemental analysis were undertaken via energy-dispersive $\mathrm{X}$-ray spectroscopy (EDS), so as to confirm nanocomposite preparation. Fig. 4 and Table 4 present the results obtained for the
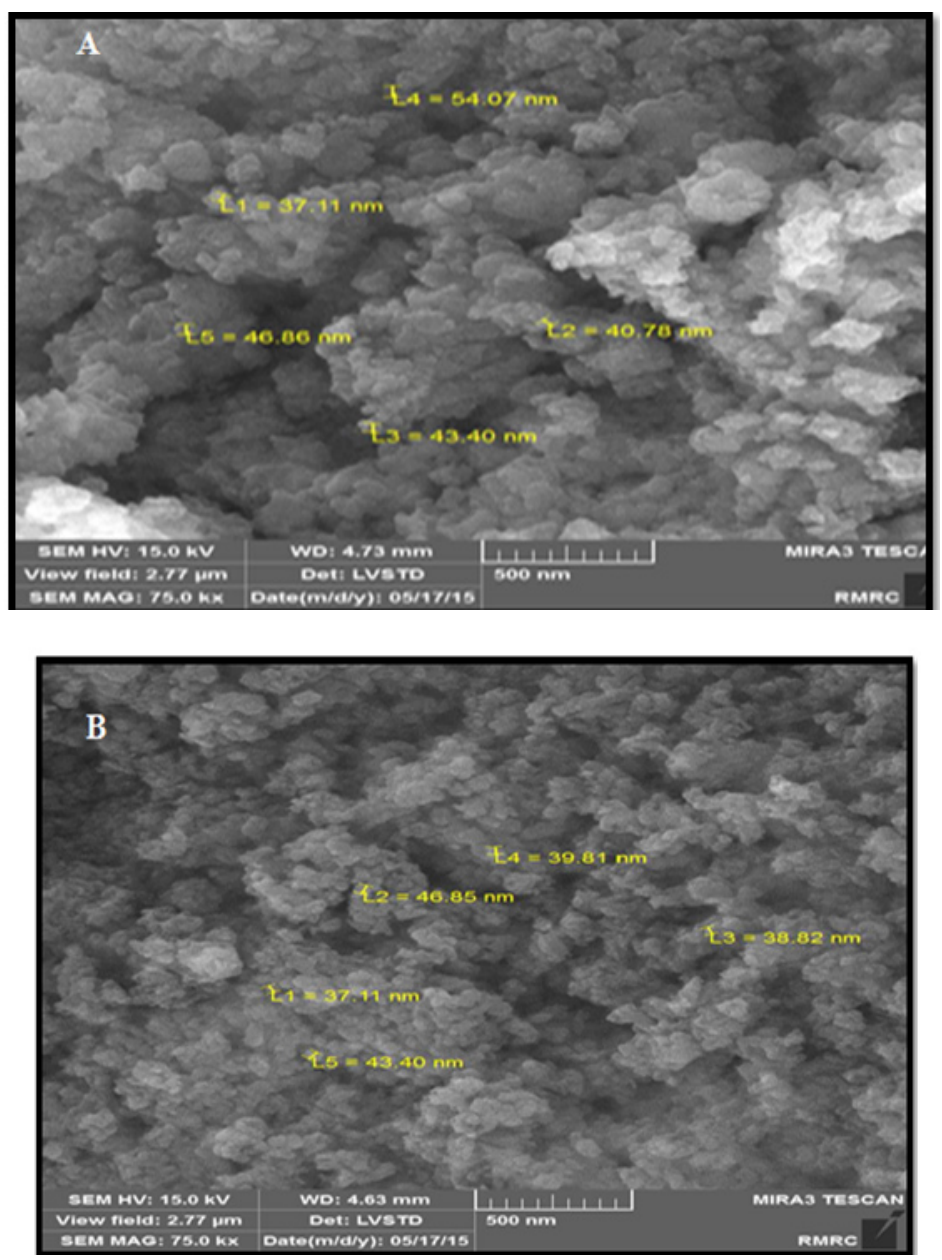

Fig. 2: FESEM images of silica nanoparticles doped in: A) HA/gelatin, and B) HA/collagen 
synthesized silica nanocomposites doped in HA/ gelatin, while Fig. 5 and Table 5 come with the corresponding results to silica nanoparticles doped in $\mathrm{HA}$ /collagen. The presence of silica in Figs. 4 and 5 and Tables 4 and 5 confirms the doping of silica in synthesized nanocomposites. Continuing with the investigations, $\mathrm{Ca} / \mathrm{P}$ ratios were calculated using the amounts of calcium and phosphorus. Accordingly, $\mathrm{Ca} / \mathrm{P}$ ratios of 1.59 (close to theoretical value) and 1.67 (equivalent to the theoretical value) were
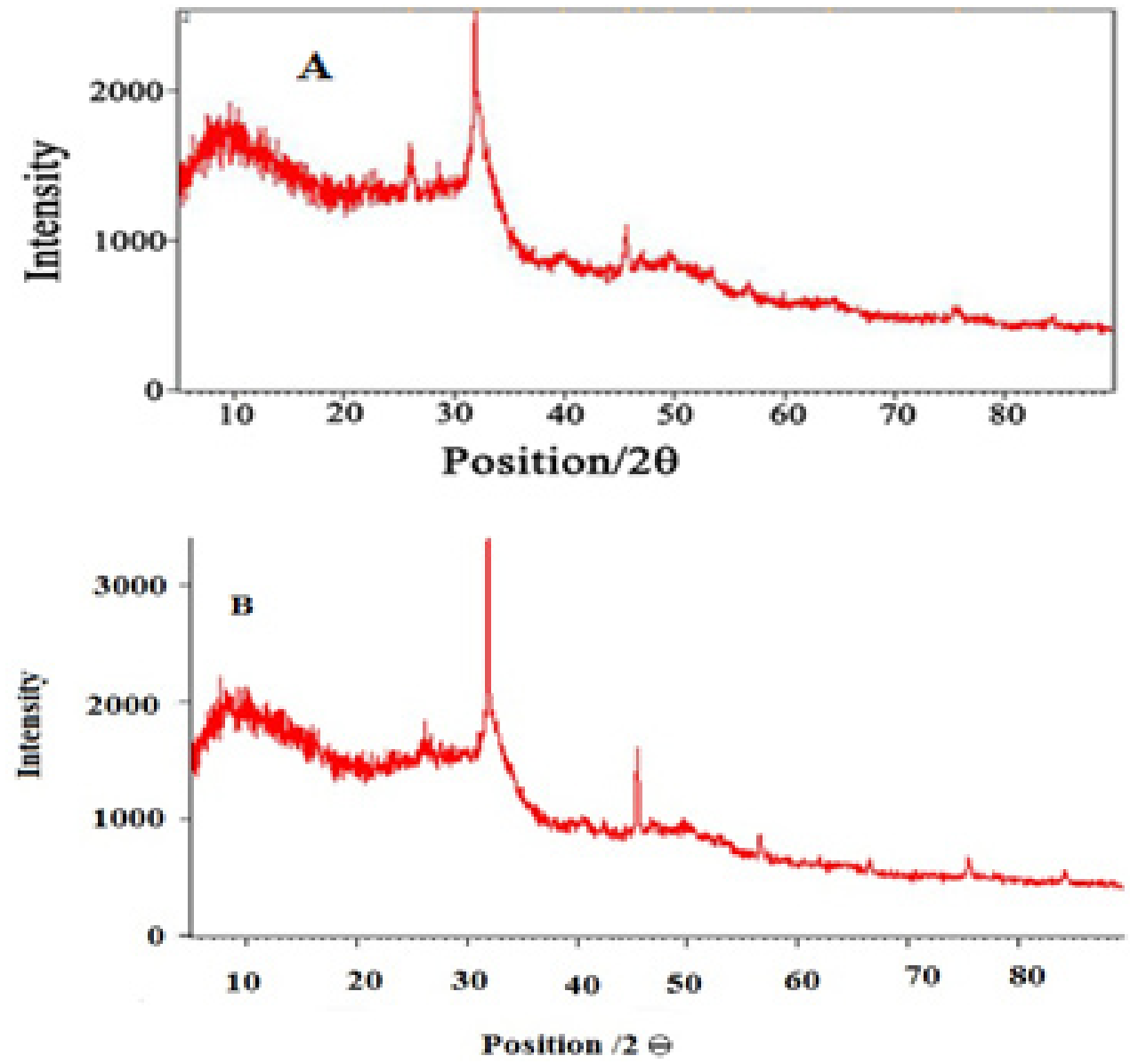

Fig. 3: XRD patterns of silica nanocomposites doped in: A) HA/collagen, and B) HA/gelatin

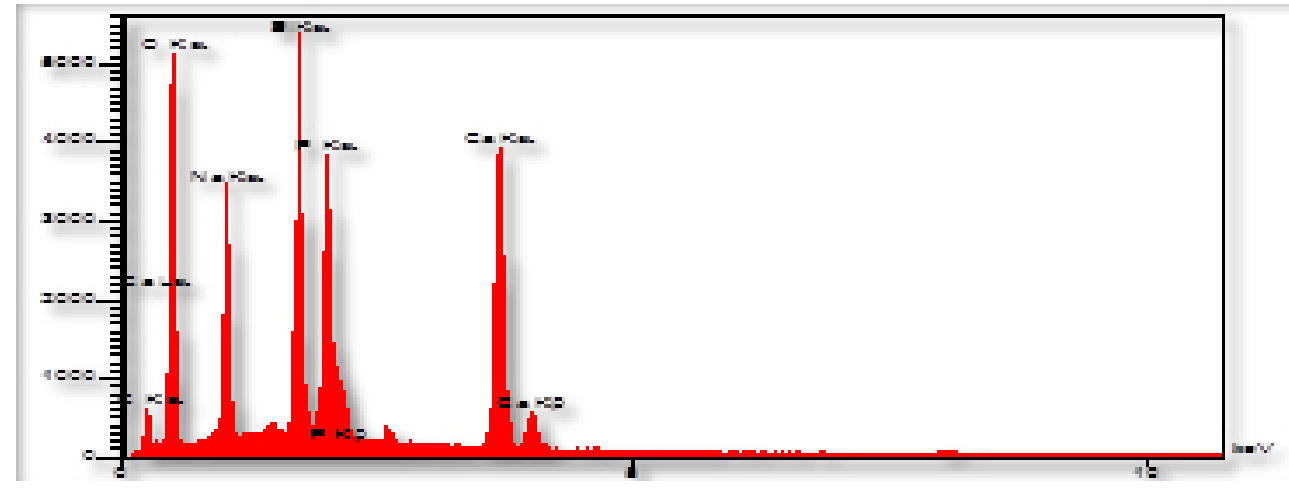

Fig. 4: EDS pattern for silica nanoparticles doped in HA/gelatin 


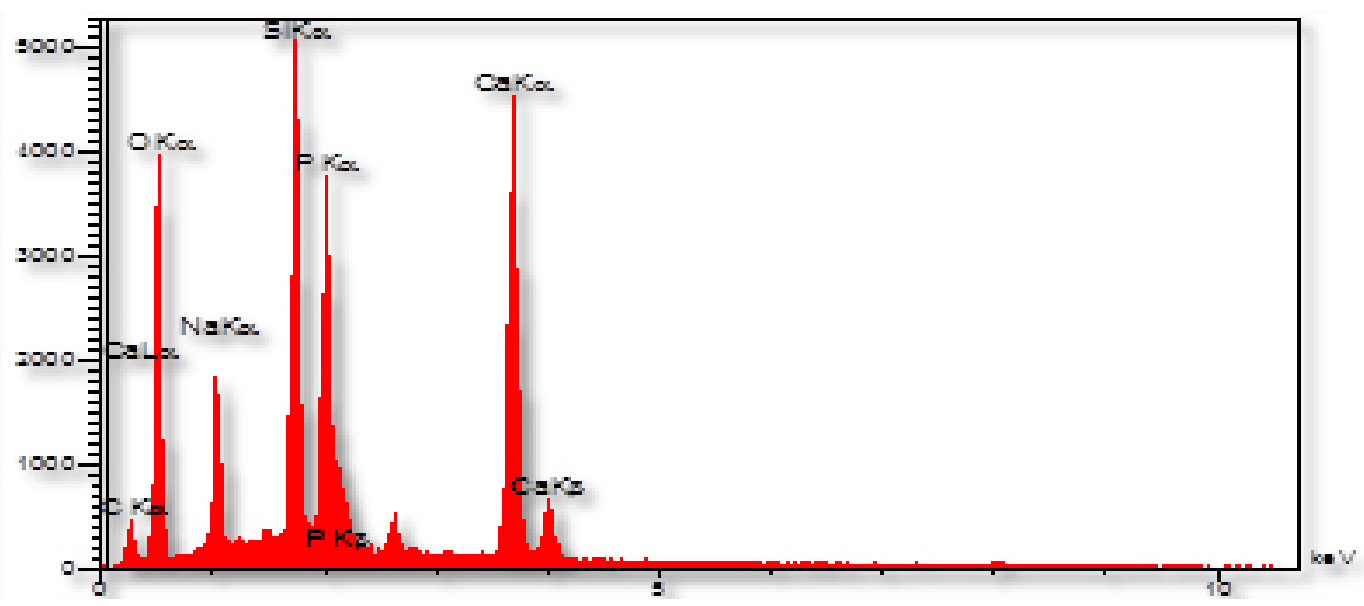

Fig. 5: EDS pattern for silica nanoparticles doped in HA/collagen

obtained for silica nanoparticles doped in $\mathrm{HA} /$ gelatin and in $\mathrm{HA} /$ collagen, respectively.

\section{CONCLUSION}

In this study, two hydrothermal HA nanocomposites were synthesized with their biocompatibilities investigated. According to the FTIR results, the synthesized HA nanocomposites had their chemical structures confirmed. Furthermore, based on the results of EDS method in terms of calcium-to-phosphorus ratios, the nanocomposites of silica doped in $\mathrm{HA} /$ collagen were observed to exhibit a $\mathrm{Ca} / \mathrm{P}$ ratio of equivalent to the theoretical value as repeated for $\mathrm{HA}$ chemical structure of $\mathrm{Ca}_{10}\left(\mathrm{PO}_{4}\right)_{6}(\mathrm{OH})_{2}$. Moreover, the results of spectroscopic XRD and SEM showed that the silica nanocomposites doped in $\mathrm{HA} /$ collagen were composed of smaller crystallite and particles than those of the silica nanocomposites doped in HA/ gelatin. As reducing crystallite size and particle size increase contact surface, the silica nanocomposites doped in $\mathrm{HA} /$ collagen are expected to exhibit higher levels of reactivity in chemical reactions, making them of better pharmacological efficacy when it comes to bone repair.

\section{REFERENCES}

1. Sadjadia M.S., Ebrahimia H.R., Meskinfamb M., Zarec K., , Materials Chemistry and Physics., 2011 130, 67-71.

2. Bizari D., Rabiee M., Moztarzadeh F., Tahriri M., Alavi S.H., Masaeli R., Bizari D., Rabiee M., Moztarzadeh F., Tahriri M., Alavi S.H., Masaeli R., Ceramics - Silikáty, 2013, 57 (3) 201-209.

3. Farzadia A., Bakhshib F., MehranSolati N., MitraAsadi-Eydivanda, Noor AzuanabuOsmana, Ceramics International, 2014 (40)6021-6029.

4. Heinemann S., Heinemann C. , Jäger M. , Neunzehn J., Wiesmann H.P. , Hanke T. , ACS Appl. Mater. Interfaces, 2011, 3 (11), 4323-4331.
5. Vallet-Regi M. and Arcos D., Materials Chemistry, 2005,. 15, pp. 1509-1516.

6. Cazalbou S., Combes C. and Rey C., Key Engineering Materials, 2001,. 92, . 13, . 192195.

7. Arcos D, Boccaccini AR, Bohner M, DíezPérez A, Epple M, Gómez-Barrena Acta Biomater, 2014, 10:1793-805.

8. Martínez-Vázquez F.J., Cabañas M.V. a, Paris J.L., Lozano D., Vallet-Regí M., Acta Biomaterialia 2015, (15) 200-209.

9. Degroot K., Geesink R., Klein C. and Serekain P., Journal of Bio- medical Materials Research, 1992,. 21,. 12. 1375-1381.

10. Jaffe W. and Scott D.," Journal of Bone and Joint Surgery, 1996, 78,. 12,. 1918-1934. 
11. Mirjam Lilja., Lindahl Carl, Wei Xia., Håkan Engqvist., Maria Strømme1., Journal of Biomaterials and Nanobiotechnology, 2013, 4, 237-241.

12. Ducheyne P., Radin S., King L., J Biomed Mater Res, 1993, 27:25-34.

13. Klaudia Paljar., Sebastijan Orliæ., Emilija Tkalèec., Hrvoje Ivankoviæ., Maruliæev trg, 2008, 19,. 177.

14. Webster T.J., Siegel R.W., Bizios R., Biomaterials, 2000; 21:1803-10.

15. Elliot J.C., 1994, Amsterdam: Elsevier Science B.V;.
16. Natalia Davidenko., Raúl G., Carrodeguas, Carlos Peniche., Yaimara Solís., Acta Biomaterialia 2010, (6) 466-476.

17. Kokubo T., Kim H.M., Kawashita M., Biomaterials, 2003, 24:2161-75.

18. Doi Y., Horiguchi T., J Biomed Mater Res, 1996, 31:43-9.

19. Rusu V.M., Ng C.H., Wilke M., Tiersch B., Fratzl P., Peter M.G., Biomaterials, 2005, 26(26):5414-26.

20. Adrian Paz., Dainelys Guadarrama., Mónica López., Jesús E., Quim. Nova, 2012, 35(9), 1724-1727. 